Article History:

Submitted:

24 November 2021

Reviewed:

14 December 2021

17 December 2021

Edited:

28 December 2021

31 December 2021

Accepted:

31 December 2021

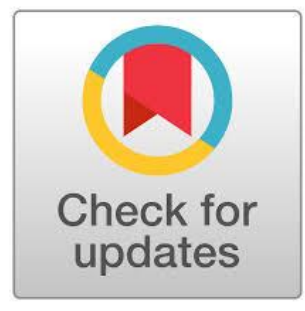

\section{Developing E-Module of Islamic Reading Text}

\section{Materials}

\author{
Astri Winandari Berlin ${ }^{*}$, Rahayu Apriliaswati, Yanti Sri Rezeki \\ Universitas Tanjungpura, Indonesia
}

${ }^{*}$ Corresponding author email: astriwinandari@gmail.com

DOI: https://doi.org/10.18196/ftl.v7i1.13210

\begin{abstract}
Providing English learning material with an Islamic basis for Madrasah Aliyah students is important as the students are Islamic learners. This research aims to develop an e-module of Islamic reading text materials for the second semester of tenth-grade students of MAN 1 Pontianak. The researchers adapted the Analyze, Design, and Develop phases of the ADDIE concept to develop this research product. The analysis phase was conducted by interviewing the English teacher to determine the suitable e-module to be designed. The design phase was done by designing the contents of the e-module based on the analysis results. The e-module consists of recount and narrative texts materials with Islamic-based stories and integrates the values of aqidah (strong belief), tawakkul (reliance upon Allah), tolerance, hard work, and husnuzon (positive thinking). In the development phase, the researchers developed the e-module then checked it with a self-designed standard evaluation checklist. The result showed that the emodule already fulfilled the criteria of appropriateness. The e-module could be supplementary reading materials to make the students' autonomous learning easier. It was written in easy-tounderstand language and provided self-instructional material with independent self-evaluation. Specifically, it is expected to improve their understanding of recount and narrative text materials and strengthen their Islamic character values.
\end{abstract}

Keywords: development research; e-module; Islamic reading text materials 


\section{Introduction}

Islamic high schools in Indonesia (Madrasah Aliyah) are expected to be the knowledge source for students based on both the national curriculum and Islamic education (Febriani, 2015). The education process in Madrasah Aliyah should inculcate Islamic religion and knowledge understanding within its teaching and learning activities. Moreover, with the focus of Curriculum 2013, where character education should be strengthened, thus educational institutions play an important role in educating the youth. In this case, Madrasah Aliyah should be the knowledge source that gives students education and character building to integrate Islamic values and knowledge. Hence, learning material is an essential part.

In English language learning, reading is among the focus skills that also have an important role in contributing to children's success both academically and in life. Thus, educators should be concerned and put careful attention to serving valuable and suitable reading material. However, based on the preliminary study of MAN 1 Pontianak, no specific Islamic reading text materials were available for the learning process of English subjects. As the Center of Madrasah education, the Islamic Education Directorate of Ministry of Religious Affairs has not released specific books or English learning material for English class in Madrasah Aliyah purpose. Ikhsanudin (2020) stated the book's availability is amongst other problems within education in Indonesia. The English teacher admitted that it is hard to find English learning materials with an Islamic basis for the English subject. To this issue, Febriani (2015) argued that the development of supplementary reading materials with Islamic values is necessary when the main book used by English teachers at Islamic High School does not cover Islamic messages.

Furthermore, the researchers developed reading materials in an electronic module, considering that students need learning materials that can be accessed easily, feasible, and interesting enough to motivate them to learn. Thus, this research aims to develop an e-module of Islamic reading text materials for the second semester of tenth-grade students of MAN 1 Pontianak. The e-module development was based on the reading text materials in Curriculum 2013 in the second semester, consisting of the recount and narrative texts.

A previous related study was from Nafiah (2020) that developed a module of procedure text reading material with Islamic values integration for the ninth-grade students of Madrasah Tsanawiyah. The study concluded that developing the English reading text materials module 
inculcated with Islamic values is appropriate and functional for English subjects in Madrasah Tsanawiyah. Another related study from Sari (2019) developed an exercise book of English reading materials with Islamic stories for an extracurricular program in Madrasah Aliyah. The result indicated that students were actively engaged and had a greater interest in reading the exercise book of English text materials with Islamic stories rather than using the general text since it was suitable with their needs and interest as Islamic learners.

Although material development is a widely discussed topic within the English language teaching context, limited research has focused on developing an electronic module of Islamic reading text material for the English subject of Madrasah Aliyah students. Through this research, the researchers filled the gap by developing an e-module of Islamic reading material for the second semester of tenth-grade students of MAN 1 Pontianak.

\section{Literature Review}

\section{Materials Development}

Tomlinson (2014) implied that material development is an effort for writers or teachers to create, evaluate, and adapt language teaching materials. Departemen Pendidikan Nasional (2008) - National Education Deepartment - mentioned that the aims of developing instructional material are for providing suitable teaching material that fulfills the demand of curriculum with consideration to the students need (in which teaching materials suit the characters or setting of the students), helping students on getting alternative teaching materials aside from textbook that is difficult to be found, and ease the teacher work.

As in this study, the researchers developed materials integrating Islamic values into English materials. It is important to put careful attention to the literature review regarding the integration of religious values into the language materials. According to Foye (2014), integrating religious values in English language teaching is applicable and will cause no problem if the language materials are taught well. Moreover, religion and education are interrelated, and the teaching materials included with religious content have implications for nation-building (Cheng \& Beigi, 2012). Hence, developing and providing the English learning material with an Islamic basis for English class in Madrasah Aliyah is critical. 


\section{Islamic Reading Text Materials}

Islamic-based reading text is a set of reading texts that gives the readers Islam-related stories that can be utilized as practical ways to introduce Islamic values in students' day-to-day lives (Susilawati, Tahrun, \& Inderawati, 2016). This research used Islamic historical events and short Islamic stories about prophethood for the reading materials. It also has Quranic verses, hadith, and Islamic terms. In Indonesia's educational field, the government, through Curriculum 2013, commanded schools to preserve eighteen educational character values in all subjects to the students. These eighteen characters are religious, honest, tolerance, disciplined, hard-working, creative, independent, democratic, curious, patriotism, nationalism, achievement appreciation, friendly/communicative, pacifism, reading interest, social caring, environmental caring, and responsible. For the materials developed in this research, the researchers focused on teaching the religiosity values of aqidah (strong belief), tawakkul (reliance upon Allah), and husnuzon (positive thinking), also tolerance and hard work values in the Islamic reading materials.

The reading text materials in the Curriculum 2013 of the second semester of tenth grade are recount and narrative texts. Recount text is the text about the past event. In this study, the recount text is about the historical recount, with Islamic historical stories that happened in the past. In her study, Harmiyanti (2019) concluded that Islamic recount text material helped students from Islamic school increase their reading skills. Not only that, but the students also had the opportunity to deepen their knowledge of Islamic history and values.

Meanwhile, according to Iranmanesh (2012), narrative texts tell stories while delivering messages. The communicative purpose of narrative text is to entertain the readers, and the generic structure consists of orientation, complication, resolution, and re-orientation, which is an optional part (Herlina, 2012). A previous related study from Faridi and Bahri (2016) explored an Islamic narrative story reading model for an English class in an Islamic junior high school. The study indicated that English classes in Islamic schools must have the Islamic narrative reading material model to help students build good character. Henceforth, Islamic stories in recount and narrative texts materials for Islamic-affiliated schools are considered suitable since the students can enhance their reading comprehension and have the opportunity to strengthen their good character. 


\section{E-module}

The key for effective learning materials development in materials development is to make them effective, efficient, and engaging (Qamariah, 2015). An electronic module can become a good option as the e-module can serve the material effectively and engagingly. According to Departemen Pendidikan Nasional (2017), an e-module presents self-systematic study material divided into certain learning units and presented electronically. Each learning activity is linked by navigation links for students to become more interactive with the program. It is also supported with video, animation, and audio presentations to enrich the students learning experience.

The characteristics of e-modules according to the Depdiknas (2017) are self-instructional (students can learn on their own), self-contained (all learning material from one competency unit being studied is contained in one complete module), stand-alone (not depending on other media), adaptive to the development of science and technology, and user friendly. Further, Depdiknas explained that an e-module is delivered using a computer-based electronic media that utilizes various electronic media functionalities. Also, the e-module should be carefully designed by taking into account learning principles and using consistent fonts, spacing, and layout.

Ahmad (2017) stated that by developing an e-module based on the students need, educators can give the students appropriate material for their independent learning and may benefit in some aspects, such as providing flexibility for adapting and connecting developed materials to students' and institutional needs, enhancing the expertise of the writer, and raising the institution's reputation. The study from Pombo, Smith, Abelha, Caixinha, and Costa (2012) that evaluates the implementation of e-module revealed that implementing an e-module can help develop ICT skills, encourage self-reflection, and make task activities more engaging. In line with that, Budiarti, Nuswowati, and Cahyono (2016) stated that e-module helps students to foster creativity and habit of productive thinking and build learning situations that are favorable, active, and innovative. Together, these studies outline that e-module positively impacts the students' learning process.

\section{Method}

This research developed an e-module of Islamic reading text materials for the second semester of tenth-grade students of MAN 1 Pontianak in the academic year 2021/2022. It was 
classified as Research and Development because through the research, the researchers developed a learning product. Wahidah, Ibrahim, \& Muslim (2019) stated that the purpose of Research and Development in the educational field is to develop effective products for school use. This research adapted Analyze, Design, and Develop phases of the ADDIE concept proposed by Branch (2009) to develop the product.

In the analysis phase, an interview with the participant of this research, an English teacher of MAN 1 Pontianak, was conducted. The aim was to find out the kind of e-module of Islamic recount and narrative text materials that should be developed based on the teacher's perspective as an experienced English teacher who has been teaching the tenth grade of Madrasah Aliyah students. The interview was a structured interview with prepared questions. Interviewing is expected to expand the understanding of the studied topic because the interview is interactive, also interviewers can ask for clear-complete information (Alshenqeeti, 2014). The thematic analysis method was used to analyze the data from the interview. Alhojailan (2012) stated that thematic analysis is used for evaluating classifications and presenting data-related themes. There were three steps in conducting the thematic analysis. The first was to comprehend the data by listening again to the interview recording and rereading its transcript. Step two was to note the core data from the interview. Then, the last step was to discover the data conclusion.

In the design phase, the contents of the e-module were designed by the researchers. The contents included the types of reading text materials, the contents of the e-module, the learning model, the Islamic values, stories, and activities for the text materials. In line with Branch (2009), the design phase's typical deliverable is a design brief. The Islamic reading text materials consisted of recount text and narrative text materials. The materials development was based on the Contextual Teaching and Learning model with its seven components: constructivism, modeling, inquiry, questioning, community learning, reflection, and authentic assessment. The stories for both text materials were based on Islamic historical and short stories that integrated the values of aqidah (strong belief), tolerance, tawakkul (reliance upon Allah), hard work, and husnuzon (positive thinking).

In develop phase, the researcher developed the e-module by arranging the designed contents using Ms. Word 2013 software. Then, the developed product was checked based on the standard evaluation checklist and finalized. The standard evaluation checklist was made by the 
researcher adapting the Teaching Materials Formative Evaluation Format in the Teaching Materials Development Guide by Departement Pendidikan Nasional 2008. There were fourteen criteria in the standard evaluation checklist that covered the evaluation of content appropriateness, language appropriateness, presentation appropriateness, and graphics.

\section{Findings}

This research adopted the phases of Analyze, Design, and Develop of the ADDIE concept proposed by Branch (2009).

\section{Analysis Phase}

The analysis phase was done through a structured interview with the English teacher to identify what kind of e-module of Islamic recount and narrative text is suitable for students from the teacher's perspective. Through the interview, the researchers found that no specific English learning material with an Islamic basis was available in MAN 1 Pontianak previously. Therefore, the product of this research acted as an initial product.

The conclusion regarding the kind of e-module suitable for the students from the analysis phase was that the e-module should be made simple with easy-to-understand language. The tenthgrade students tended to have a low reading mastery level, specifically recount and narrative text. They lacked vocabulary, especially past tense vocabulary; subsequently, the e-module should be made with common and familiar vocabularies.

Then, the teacher suggested that the researcher make the reading text materials short and with not hard exercises. She said: "My suggestion is to make the e-module simple with not long texts and written in easy-to-understand language and don't make the tasks and exercises parts difficult. Make the exercises easy to medium level". Moreover, to draw the students' attention, the teacher suggested putting supporting pictures for the text. She said: "Students tend to pay more attention to the reading texts that are short and have supporting pictures, so give the text supporting pictures or illustration". Thus, the researchers put supporting pictures for the texts.

\section{Design Phase}

The design phase was conducted by designing the contents of the e-module. It consisted of preparing the reading text materials, the contents of the e-module, the learning model, the Islamic values, stories, and activities for the text materials. 
Reading text materials. The design of reading text materials of the e-module was based on the tenth grade English subject syllabus of curriculum 2013 that the English teacher uses. The types of reading text materials of the second semester in the syllabus are recount and narrative texts. The standard competencies of recount text in the syllabus are students able to: 1 ) identify the social function, text structure, and language features of recount text, 2) conclude the meaning of the text, and 3) arrange the recount text. While the standard competencies of narrative text in the syllabus are students able to 1) identify the social function, text structure, and language features of narrative text, 2) conclude the meaning of the text. The core and standard competence are written in each module's chapter.

The contents of the e-module. The researchers made the text materials and stories from several sources. The book sources were from the students' book of English subject from the Ministry of Education, students' book of Akidah Akhlak also Sejarah Kebudayaan Islam from the Ministry of Religious Affairs. The researcher compiled and rewrote the explanation and stories from those books to be adjusted to the students' level by simplifying the language to understand the text and materials easily. It was also to avoid plagiarism. Furthermore, as the recount and narrative texts topic is about Islamic stories and character values, the researcher also completed the content of the e-module with Quranic verses. For the Quranic verses, the researchers used the web of https://quran.com/ as the source. The researchers gave credit to those books and web used by putting them on the reference page of the e-module. To support the text in the e-module and to draw the students' interest, supporting illustrations and pictures that visualize the stories were added in the text. The sources of those contents addresses were put under each of them. Moreover, to enrich the students learning experience and for the students' listening practice, some YouTube video links related to the reading text materials and the stories were also inserted in the e-module, and their hyperlinks are put on the pages that discuss them.

Learning Model. Contextual Teaching and Learning (CTL) was chosen for the learning model. CTL is considered the most suitable learning model for materials development in this research since CTL's objective is to motivate students to comprehend the meaning of learning materials based on their prior knowledge. According to Johnson (as cited in Kadir, 2011), CTL is an educational process aiming at guiding students for meaning derivation from the academic materials the students are studying by linking the 
topic towards their everyday life circumstances. CTL model consists of seven components, namely constructivism, modeling, inquiry, questioning, community learning, reflection, and authentic assessment.

In the constructivism part, brainstorming questions are given to construct knowledge as in this initial stage of CTL students should construct their knowledge based on prior knowledge. In the modeling part, the materials models are given so that the students can adapt them. In the inquiry part, the text to be observed is given to analyze and understand the materials. In the questioning part, the questions are given to assess the students' thinking. The questions are adjusted to the students' level. In the community learning part, it is the part for students to share their ideas or experiences and work together. In the reflection part, the students reflect on what has been learned and respond to it based on prior knowledge and experience. Lastly, in the authentic assessment part, it is the part to ensure the students' capability and learning development.

Islamic values, stories, and activities. As the Islamic values would be integrated within the reading text materials of the e-module, thus another learning objective which is to connect the values from the stories to the student's daily life was added to each chapter's learning objective. The values taught in the recount text focus on aqidah (strong belief), tolerance, and tawakkul (reliance upon Allah). They are husnuzon (positive thinking) and hard work in the narrative text. Those values are chosen since they are the focus values strengthening in Akidah Akhlak subject of tenth-grade and among the eighteen character education values of Curriculum 2013.

Furthermore, the Islamic stories for the recount text materials are stories about Islamic historical events. They were the histories of Hijrah to Medina, the Hudaibiyah Treaty, Isra' Miraj, Kaaba, and the Medina Charter. The stories were chosen since the values of aqidah, tolerance, and tawakkul as the values that want to be integrated into the recount text chapter lie within the stories. In another hand, the Islamic stories for narrative text materials are about Zamzam water, Prophet Nuh, The Moon Split, and The Battle of Badr. The stories are chosen since the values of husnuzon and hard work as the values that want to be integrated into narrative text lies within the stories.

The researcher also inserted several additional parts, such as intermezzo and character 
development parts, discussing Islamic values. Besides, there are activities parts for the students to reflect on their prior knowledge and daily life situation, and glossary parts of words related to Islamic terms.

\section{Develop Phase}

In the development phase, the e-module was developed by arranging the collected contents into an e-module using Ms. Word 2013. Hyperlinks were also integrated with the emodule for online learning sources from YouTube and hyperlinks of exercises to submit and check the students' work through Google form. The researcher adapted the guide from Panduan Praktis Penyusunan E-modul Tahun 2017 by Departemen Pendidikan Nasional for developing the outline of the e-module.

After developing the e-module, the researcher evaluated it with a standard evaluation checklist. Fourteen criteria covered the evaluation of content appropriateness, language appropriateness, presentation appropriateness, and graphics.

The result showed that this study's product, the e-module of Islamic reading materials for the second semester of tenth-grade students of MAN 1 Pontianak, already fulfilled all appropriateness criteria.

Table 1. Standard evaluation checklist results

\begin{tabular}{|c|c|c|c|c|}
\hline No & Aspect & Indicator & & \\
\hline . & & & Yes & No \\
\hline 1. & $\begin{array}{c}\text { Content } \\
\text { Appropriateness }\end{array}$ & $\begin{array}{l}\text { E-module materials are suitable with the standard } \\
\text { competence and basic competence }\end{array}$ & $\sqrt{ }$ & \\
\hline 2. & & $\begin{array}{l}\text { Material contents are fit to the student's } \\
\text { competency level }\end{array}$ & $\sqrt{ }$ & \\
\hline 3. & & The Islamic stories are useful for the students & $\sqrt{ }$ & \\
\hline 4. & & The contents are following moral values & $\sqrt{ }$ & \\
\hline 5. & $\begin{array}{c}\text { Language } \\
\text { Appropriateness }\end{array}$ & $\begin{array}{l}\text { The language used is according to the } \\
\text { grammatical rules of English }\end{array}$ & $\sqrt{ }$ & \\
\hline 6. & & The e-modul is clear and readable & $\sqrt{ }$ & \\
\hline 7. & & Effective use of language & $\sqrt{ }$ & \\
\hline 8. & Presentation & Learning objectives are clear & $\sqrt{ }$ & \\
\hline 9. & Appropriateness & Presentation of the material is in order & $\sqrt{ }$ & \\
\hline 10. & & Supporting pictures are available & $\sqrt{ }$ & \\
\hline
\end{tabular}




\begin{tabular}{|c|c|c|c|c|}
\hline \multirow[t]{2}{*}{ No } & \multirow[t]{2}{*}{ Aspect } & \multirow[t]{2}{*}{ Indicator } & \multirow[b]{2}{*}{ Yes } & \multirow[b]{2}{*}{$\mathrm{No}$} \\
\hline & & & & \\
\hline 11. & Graphics & The font used is not excessive & $\sqrt{ }$ & \\
\hline 12. & & The layout is clear & $\sqrt{ }$ & \\
\hline 13. & & $\begin{array}{l}\text { Pictures and presentations are interesting and can } \\
\text { support the reading materials }\end{array}$ & $\sqrt{ }$ & \\
\hline 14. & & The display design is interesting & $\sqrt{ }$ & \\
\hline
\end{tabular}

The researcher also showed the result to the English teacher to ask for her judgment. It turned out that the English teacher of MAN 1 Pontianak was pleased with the resulting product. She expressed her contentment that the e-module materials were clear, easy to read, and had good Islamic stories. The overall design and content were also simple and interesting enough. Hence, it was finalized in which the file was saved as a Portable Document Format (PDF) file.

\section{Resulted Product}

The product of this research is an e-module of Islamic reading text materials. The emodule is packaged in a shareable PDF File that can be accessed easily and feasible with computer-based electronic devices. The product is located in Google Drive and can be accessed through the link: https://bit.ly/32f9Ck8

The e-module is written by adjusting to the students' level. The language and vocabulary used are simplified to understand the text and materials easily. The e-module is equipped with self-instructional material, user guidelines, hyperlinks that can navigate students to internet learning sources and exercise links, and self-evaluation parts to evaluate their learning independently. The e-module also has interesting media such as supporting pictures and presentations for richer independent learning experiences.

The e-module consists of materials for the recount and narrative texts. The recount text materials use Islamic historical stories of Hijrah to Medina, Hudaibiyah Treaty, Isra' Miraj, Kaaba, and Medina Charter and integrate the values of aqidah (strong belief), tolerance, and tawakkul (reliance upon Allah). The narrative text materials use Islamic short stories of Zam-zam water, Prophet Nuh, The Moon Split, and The Battle of Badr and integrate the values of hard work and husnuzon (positive thinking). 
The total number of pages of the e-module is 29 pages, with the layout being simple in blue and green lines. The e-module is written with Times New Roman 12 as the main font for most of the text, the titles with Arial Rounded 14, and subtitles with Cambria Math 14. The emodule can be used as supplementary materials for independent learning. Through the emodule, students can learn the recount text and narrative text materials and have the opportunity to learn Islamic stories and strengthen their character based on Islamic values.

\section{Discussions}

Providing the English learning material with an Islamic basis for English subjects in Madrasah Aliyah is an important effort as the students in Madrasah Aliyah are Islamic learners. The pre-research study found that no English learning material with an Islamic basis was available for the English class in Madrasah Aliyah Negeri 1 Pontianak. This is unfortunate since the school is an Islamic school that should strengthen religious education. Febriani (2015) argued the development of supplementary reading materials with Islamic values is necessary when the main book used by the English teacher at Islamic High School does not cover Islamic messages. In the same vein, Madkur and Albantani (2017) state that it is important for foreign language teachers in Indonesia as the country where there are many Islamic schools exist to integrate Islamic values. It is important because the educators teach Islamic values through their classes in Islamic schools. Then, the researcher aimed to develop an e-module of Islamic reading text materials for the second semester of tenth-grade students of MAN 1 Pontianak.

The researchers adopted the Analyze, Design, and Develop phases of the ADDIE concept proposed by Branch (2009) to develop the resulting product. In the analysis phase, the interview concluded that students need reading text materials that are easy to understand and simple as they have low mastery levels and lack of vocabulary. Also, students are interested in reading short texts and have supporting pictures. The teacher also suggested making the exercises not hard.

The design phase was done by designing the contents of the e-module. The materials were arranged with easy-to-understand language, not-so-long stories and texts of each chapter and supported with illustrations and pictures to engage the students. Foye (2014) concluded that ELT teachers generally recognize religion's importance in many people's lives and as a vital character to a nation that it is applicable to be the topic for ELT, the topic of the e-module contents is 
Islamic based reading text. The stories contained in both texts are Islamic-based stories with values of aqidah (strong belief), tolerance, tawakkul (reliance upon Allah), hard work, and husnuzon (positive thinking). Sari (2019) indicated that reading materials with Islamic stories could help students improve their reading ability and Islamic values understanding in Madrasah Aliyah. Accordingly, the researchers also believe that this e-module will help the students improve their reading text materials understanding and strengthen their Islamic character values.

The e-module was developed, checked, and finalized in the development phase. The emodule was arranged clearly and decently, and the check result of appropriateness showed that it already fulfilled all the appropriateness criteria. The e-module can be accessed easily with computer-based electronic devices as it is a PDF file located on Google drive. The e-module is equipped with self-instructional material, user guidelines, hyperlinks that can navigate students to internet learning sources and exercise links, and self-evaluation parts to evaluate their learning independently. The e-module also has interesting media such as supporting pictures and presentations for richer independent learning experiences.

The e-module as the product of this research answered the aims of material development from Departemen Pendidikan Nasional (2008). According to Depdiknas, the aims of material development are for providing suitable teaching material that fulfills the demand of curriculum with consideration to the students need (in which teaching materials suit the characters or setting of the students), helping students on getting alternative teaching materials aside from textbook that difficult to be found, and ease the teacher work. The e-module has fulfilled the demand of the curriculum and adjusted towards the students' needs and status as Muslim learners. Moreover, it can help the teacher provide learning materials with Islamic bases for the students of MAN 1 Pontianak that were previously unavailable.

The e-module also has the characteristics of the electronic module mentioned by Departemen Pendidikan Nasional (2017). In the resulting e-module, all learning material from the studied competency units is contained in one complete module. It is not dependant on other media, and is adaptive to the development of science and technology, also user-friendly. Through the e-module, students can learn on their own without the presence of the teacher.

It can be stated that the strength of this research product is that the e-module is arranged based on the student level with simple and easy-to-understand language. The e-module can be 
used as supplementary materials to make students' independent learning easier. Ahmad (2017) mentioned that in achieving learning outcomes, it is necessary to have an appropriate set of materials that students can easily understand during the learning process, both in and out of the classroom. The students can also have the opportunity to learn English reading materials and strengthen their Islamic character values through the e-module. It is located on Google Drive with a sharing link, making the e-module feasible and accessible.

\section{Conclusion}

This research aims to develop an e-module of Islamic reading text materials for the second semester of tenth-grade students of MAN 1 Pontianak. This research was conducted by adapting Analyze, Design, and Develop phases of the ADDIE concept proposed by Branch (2009). The emodule consists of reading materials of the recount and narrative texts with Islamic stories and integrates the values of aqidah (strong belief), tolerance, tawakkul (reliance upon Allah), hard work, and husnuzon (positive thinking). The e-module can make the students' autonomous learning easier as it was written in easy-to-understand language and provided self-instructional material with independent self-evaluation. It can be used as supplementary reading materials to support independent learning, especially during the COVID-19 pandemic. Specifically, it is expected to improve their understanding of recount and narrative text materials and strengthen their Islamic character values. However, the e-module also has some limitations. The e-module is still an initial product for MAN 1 Pontianak students. In another hand, the e-module was not validated by the experts but was limited by the researcher, and it is not yet tried out to the students. It is hoped that other researchers can continue this research by implementing the resulting product and doing the evaluation phase.

\section{References}

Ahmad, A. (2017). Developing cooperative learning-based E-Module to teach basic English grammar of the first semester of English study program students at FKIP-UIR. J-SHMIC: Journal of English for Academic, 4(2), 1-11. https://doi.org/10.25299/jshmic.2017.vol4(2).536 
Alhojailan, M. I. (2012). Thematic analysis: A critical review of its process and evaluation. West East Journal of Social Sciences, 1(1), 39-47. Retrieved from https://fac.ksu.edu.sa/sites/default/files/ta thematic analysis dr mohamme $\underline{\mathrm{d} \text { alhojailan.pdf }}$

Alshenqeeti, H. (2014). Interviewing as a data collection method: A critical review. English linguistics research, 3(1), 39-45. https://doi.org/10.5430/elr.v3n1p39

Branch, R. M. (2009). Instructional design: The ADDIE approach (Vol. 722). Springer Science \& Business Media.

Budiarti, S., Nuswowati, M., \& Cahyono, E. (2016). Guided inquiry berbantuan e-modul untuk meningkatkan keterampilan berpikir kritis. Journal of Innovative Science Education, 5(2), 144-151. Retrieved from https://journal.unnes.ac.id/sju/index.php/jise/article/view/14264/7795

Cheng, K. K. Y., \& Beigi, A. B. (2012). Education and religion in Iran: The inclusiveness of EFL (English as a Foreign Language) textbooks. International Journal of Educational Development, 32(2), 310-315. http://dx.doi.org/10.1016/j.ijedudev.2011.05.006

Departemen Pendidikan Nasional. (2008). Panduan pengembangan bahan ajar sekolah menengah atas. Jakarta: Direktorat Jenderal Manajemen Pendidikan Dasar dan Menengah

Departemen Pendidikan Nasional. (2017). Panduan praktis penyusunan E-modul tahun 2017. Jakarta: Direktorat Jenderal Pendidikan Dasar dan Menengah

Faridi, A., \& Bahri, S. (2016). Developing English Islamic narrative story reading model in Islamic junior high school. Arab World English Journal (AWEJ), 7(2), 224-243. https://dx.doi.org/10.24093/awej/vol7no2.15

Febriani, H. (2015). Developing supplementary reading materials for Islamic learners of MAN 03 Malang based on genre-based approach. Journal of Linguistics and Language Teaching, 2(1). Retrieved from https://ejournal.iainbengkulu.ac.id/index.php/linguists/article/view/123/118

Foye, K. (2014). Religion in the ELT classroom: Teachers' perspectives. Language Teacher, 38(2), 5-12. https://doi.org/10.37546/JALTTLT38.2-1

Harmiyanti, R. (2019). Developing a model of Islamic recount text material for the tenth graders of SMA IP (Islam Plus) Al-Banjari Blora in the academic year of 2019/2020 [Bachelor thesis]. Retrieved from http://eprints.walisongo.ac.id/11195/1/NIM1403046052.pdf 
Herlina. (2012). Developing reading narrative text materials for eighth graders of junior high school implemented with character Building. English Education Journal, 2(2), 147- 154. Retrieved from https://journal.unnes.ac.id/sju/index.php/eej/article/view/675/658

Ikhsanudin, I. (2020). Providing electronic coursebook for school learners nationwide: Indonesian experience. In Anshori, D. S., Purnawarman, P., Gunawan, W., \& Wirza, Y. (Eds), language, education, and policy for the changing society: contemporary theory and research (124-140). UPI Press.

Iranmanesh, Z. (2012). Narrative prose and its different types. Journal of Languages and Culture, 4(8), 125 - 131. Retrieved from https://academicjournals.org/journal/JLC/article-fulltext-pdf/237E31A10065

Kadir, A. (2011). Teaching reading using Contextual Teaching and Learning (CTL) [Bachelor thesis]. Retrieved from https://repository.uinjkt.ac.id/dspace/handle/123456789/469

Madkur, A., \& Albantani, A. M. (2017, October). Instilling Islamic values in foreign language teaching: An Indonesian context. Proceedings of the International Conference on Education in Muslim Society (ICEMS 2017), 115, 97-103. https://dx.doi.org/10.2991/icems-17.2018.20

Nafiah, U. (2020). Developing English modules with integrated Islamic values and Jambi local wisdom. Studies in English Language and Education, 7(1), 96-112. Retrieved from http://jurnal.unsyiah.ac.id/SiELE/article/view/15138

Pombo, L., Smith, M., Abelha, M., Caixinha, H., \& Costa, N. (2012). Evaluating an online emodule for Portuguese primary teachers: Trainees' perceptions. Technology, Pedagogy and Education, 21(1), 21-36. http://dx.doi.org/10.1080/1475939X.2011.589156

Qamariah, Z. (2015). Developing Islamic English Instructional materials based on school-based curriculum. Journal on English as a Foreign Language, 5(2), 99-111. https://doi.org/10.23971/jefl.v5i2.370

Sari, A. S. (2019). Developing reading supplementary materials using Islamic stories for an extracurricular program of Islamic Senior High School level. Language-Edu, 8(2). Retrieved from http://riset.unisma.ac.id/index.php/LANG/article/viewFile/2805/pdf

Susilawati, S., Tahrun, T., \& Inderawati, R. (2016). Developing Islamic-based reading materials for the tenth graders of MA Nurul Huda Kasmaran of Babat Toman. Proceedings of the 2nd Sriwijaya University Learning and Education 50 International Conference, 2(1), 1155-1176. Retrieved from http://conference.unsri.ac.id/index.php/sule/article/view/90/pdf

Tomlinson, B. (2014). Developing materials for language teaching (2 ${ }^{\text {nd }}$ ed.). Bloomsbury Academic 
Journal of Foreign Language Teaching and Learning

Volume 7, No. 1, January 2022

Available online at: https://journal.umy.ac.id/index.php/FTL/issue/view/833

e-ISSN: 2580-2070, p-ISSN: $2527-7650$

Wahidah, N., I., Ibrahim, N., \& Muslim, S. (2019). E-Module: Design a learning material with rowntree and hannafin model for higher education. International Journal of Scientific $\mathbb{E}$ Technology Research, 8(12), 3373-3376. Retrieved from http://www.ijstr.org/paperreferences.php?ref=IJSTR-1219-26531 